\title{
PROBLEMATIKA PENGAJARAN BAHASA ARAB DI MADRASAH ALIYAH
}

\author{
Agus Supriadi, Akla, J. Sutarjo \\ Institut Agama Islam Negeri Metro \\ email: agusfaqod123@gmail.com
}

\begin{abstract}
This study aimed to analyze the problematics of teaching Arabic students in Islamic Senior High School. The method in this research was qualitative with a case study approach. This research was conducted at Islamic Senior High School Raudlatul Hidayah Ma'arif Nahdlatul Ulama 03 Mengandungsari. Research samples were 30 students of grade XI. Data collection methods in this study were observation and interviews. Data analysis techniques used descriptive qualitative analysis. The results showed that teaching Arabic in Islamic Senior High School included two main problems: linguistic and nonlinguistic problems. Linguistic problems were problems experienced by students during the learning process, and these problems were still related to parts of the language component. Linguistic problems included three main issues that became problematic in Arabic teaching, and they were phoneme problems (ashwat), vocabulary problems (mufrodat), and grammatical problems (qowaid/ nahwu/ tarkib). At the same time, nonlinguistic problems were problems which were not part of the language element. Such as teacher taught students, lack of motivation towards students, learning media, facilities and infrastructure that were still inadequate during the Arabic learning process.
\end{abstract}

Keywords: Arabic; Learning Problematic; School; Learners.

\begin{abstract}
Abstrak
Penelitian ini bertujuan untuk menganalisis problematika pengajaran bahasa Arab di Madrasah Aliyah. Metode dalam penelitian ini adalah kualitatif dengan pendekatan studi kasus. Penelitian ini dilakukan di Madrasah Aliyah Raudlatul Hidayah Ma'arif Nahdlatul Ulama 03 Mengandungsari. Sampel penelitian
\end{abstract}


adalah 30 siswa kelas XI. Metode pengumpulan data dalam penelitian ini adalah observasi dan wawancara. Teknik analisis data menggunakan analisis deskriptif kualitatif. Hasil penelitian menunjukkan bahwa problematika pembelajaran bahasa Arab di Madrasah Aliyah meliputi dua masalah pokok, yaitu masalah linguistik dan nonlinguistik. Masalah kebahasaan merupakan masalah yang dialami siswa selama proses pembelajaran yang masih berhubungan dengan bagian komponen bahasa. Masalah kebahasaan meliputi tiga masalah utama yang menjadi problematis dalam pengajaran bahasa Arab, yaitu masalah bunyi (ashwat), masalah kosakata (mufrodat), dan masalah tata bahasa (qowaid/ nahwu/ tarkib). Sedangkan masalah non linguistik adalah masalah yang bukan merupakan bagian dari unsur bahasa. Seperti guru mengajar siswa, kurangnya motivasi siswa, media pembelajaran, sarana prasarana yang masih kurang memadai selama proses pembelajaran bahasa Arab.

Kata Kunci: Bahasa Arab; Problematika Pembelajaran; Sekolah; Peserta Didik.

\section{A. Pendahuluan}

Pengajaran bahasa Arab pada peserta didik Madrasah Aliyah dihadapkan pada berbagai problema. Problema-problema yang dirasakan berupa problema linguistik dan problema non linguistik. Problematika merupakan sesuatu bentuk pola yang berbeda dengan bahasa satu dengan bahasa yang lainnya. Problematika dalam proses pengajaran kebahasaan merupakan suatu kendala yang bisa menghambat proses pembelajaran. Problema itu akan terlihat dari linguistik dan non linguistik baik pendidik atau peserta didik. Problematika linguistik yang dihadapi oleh peserta didik adalah sifat dari bahasa Arab itu sendiri yang merupakan bahasa Asing. Bagi seorang pendidik mengalami problema kurangnya penerapan pengajaran terhadap peserta didik dan terbatasnya dalam penguasaan materi serta sarana dan prasarana yang kurang mendukung. Problematika non linguistik merupakan problema yang timbul dari konteks luar dari kebahasaan itu sendiri, kultur budaya, sosial serta tata bahasa yang sangat berbeda antara bahasa Arab dengan bahasa Indonesia. ${ }^{1}$

Masalah yang biasanya muncul pendidik terlalu monoton dalam penyampaian materi. Misalnya dalam proses pengajaran pendidik menggunakan sistem menerjemahkan bahasa Arab tanpa pemahaman kepada peserta didik, pendidik hanya memberikan mufrodat baru. Karena menerjemah merupakan kegiatan yang tidak mudah, maksudnya membutuhkan berbagai kemampuan secara bersamaan dalam dua bahasa. ${ }^{2}$

\footnotetext{
${ }^{1}$ Nandang Sarip Hidayat, "Problematika Pembelajaran Bahasa Arab," An-Nida' 37, no. 1 (2012): 82-88, http://ejournal.uin-suska.ac.id/index.php/Anida/article/view/315.

${ }^{2}$ Khoirurrijal dkk., Interpretasi Makna (Prosedur Penerjemahan Arab - Indonesia) (Yogyakarta: Idea Press, 2019), 37.
} 
Pentingnya mengkaji problema yang dialami peserta didik akan melahirkan langkah-langkah penyelesaian yang akurat, sehingga tujuan pengajaran bisa dicapai secara maksimal. Siswanto menjelaskan bahwa tercapainya pembelajaran itu dapat dipengaruhi oleh beberapa hal yaitu tentang penguasaan metode, media, motivasi dan daya pemikiran peserta didik. ${ }^{3}$ Dalam konteks proses belajar mengajar atau pengajaran faktor yang menyebabkan kegagalan atau problema peserta didik dapat dilihat dari segi input, proses, ataupun output. Pendidikan di Indonesia memandang peserta didik yang menghasilkan belajar yang rendah dan kurang, yang disebabkan problema belajar. Untuk mengetahui peserta didik yang mengalami problema dalam belajar maka membutuhkan diagnosis kesulitan belajar. Diagnosis kesulitan belajar adalah upaya sistematis yang dilakukan oleh seorang pendidik untuk memahami secara mendalam peserta didik yang mengalami kesulitan dalam memahami materi. ${ }^{4}$

Keberhasilan peserta didik dapat diukur dari peran seorang pendidik dalam proses pengajaran yang disampaikan kepada peserta didik. Peran seorang pendidik sangat penting saat berlangsungnya proses pengajaran terhadap peserta didik (yang utama), dengan sesama pendidik lainnya, dan terhadap pekerja-pekerja lainnya. Sebagai seorang pendidik mengharapkan pembelajarannya mencapai tujuan yang diinginkan, tetapi dari proses pembelajaran banyak sekali kendala yang dihadapi oleh seorang pendidik khususnya terhadap peserta didik, apalagi pengajaran kebahasaan yang membutuhkan kepekaan peserta didik. ${ }^{5}$ Dalam proses pembelajaran kebahasaan banyak bagian-bagian atau komponen-komponen yang perlu dipelajari oleh peserta didik, yang mana komponen itu merupakan satu kesatuan yang sangat berkaitan dan tidak bisa dipisahkan satu sama lain. Bagian-bagian atau komponen-komponen ini terdiri dari bunyi bahasa (ashwat), kosakata bahasa (mufrodat) dan tata bahasa.

Peneliti problematika pengajaran bahasa Arab terdahulu menjelaskan bahwa problem yang paling dialami oleh peserta didik adalah problematika linguistik dan problematika non linguistik. Dalam problematika linguistik

\footnotetext{
${ }^{3}$ Valiant Lukad Perdana Sutrisno dan Budi Tri Siswanto, “Faktor-Faktor Yang Mempengaruhi Hasil Belajar Siswa Pada Pembelajaran Praktik Kelistrikan Otomotif SMK Di Kota Yogyakarta," Jurnal Pendidikan Vokasi 6, no. 1 (2016): 111, https://doi.org/10.21831/jpv.v6i1.8118.

${ }^{4}$ Heronimus Delu Pingge dan Muhammad Nur Wangid, "Faktor Yang Mempengaruhi Hasil Belajar Siswa Sekolah Dasar Di Kecamatan Kota Tambolaka," Jurnal JPSD (Jurnal Pendidikan Sekolah Dasar) 2, no. 2 (2016): 107, http://journal.uad.ac.id/index.php/JPSD/article/view/4947.

${ }^{5}$ Mohammad Thoha, "Pembelajaran Bahasa Arab Dengan Pendekatan Manajemen Berbasis Sekolah," OKARA: Jurnal Bahasa Dan Sastra 6, no. 1 (2012), http://ejournal.iainmadura.ac.id/index.php/okara/article/view/420.
} 
peserta didik kurang mampu menguasai tentang tata bahasa, bunyi dan kosakata bahasa Arab. ${ }^{6}$ Begitu pun problematika pengajaran bahasa Arab non linguistik yang menimbulkan masalah bagi peserta didik saat menerima materi yang diajarkan. Pendidik kurang menguasai materi yang diajarkan, metode yang kurang efisien, motivasi terhadap peserta didik yang kurang diperhatikan dan penggunaan media yang tidak baik. ${ }^{7}$ Selain itu ada beberapa faktor yang mempengaruhi tentang pembelajaran peserta didik. Yang mana faktor tersebut telah menghambat bagi peserta didik. Faktor yang paling utama adalah faktor internal dan faktor eksternal. ${ }^{8}$

Problema pengajaran bahasa Arab pada peserta didik Madrasah Aliyah dianalisis berasal dari dua problem utama. Pertama, problema linguistik merupakan problema yang sangat berpengaruh dalam proses pembelajaran peserta didik. Linguistik merupakan seperangkat software pada peserta didik saat pembelajaran berlangsung. Kedua, problematika non linguistik yang pada kali ini diakibatkan dari luar atau hardware, akan tetapi masih berpengaruh di dalam proses pembelajaran. Seorang pendidik yang kurangnya pemahaman terhadap penggunaan dan penyampaian materi oleh seorang pendidik kepada peserta didik, sehingga kurang optimal. Problema linguistik dan problema non linguistik dalam penelitian ini didapatkan data dari hasil observasi dan wawancara terhadap subjek yang bersangkutan.

Isu utama problema dalam pengajaran bahasa Arab meliputi problema linguistik dan non linguistik. Maka pertanyaan penelitian dirumuskan; Bagaimana problematika pengajaran bahasa Arab peserta didik di Madrasah Aliyah? Penelitian ini didasari oleh argumentasi bahwa problematika pengajaran bahasa Arab yang selalu dialami oleh peserta didik dalam proses pembelajaran. Dalam pengajaran kebahasaan terkhususnya bahasa Arab selalu dihadapkan oleh berbagai problema-problema yang harus dicarikan penyelesaiannya. Keterampilan guru dalam melaksanakan proses pembelajaran akan mampu meminimalisir berbagai problem yang dihadapi. Di antaranya adalah penggunaan strategi pembelajaran dengan melibatkan peserta didik aktif dan memanfaatkan media yang menarik secara optimal.

\footnotetext{
${ }^{6}$ Albarra Sarbaini, "Problematika Pengajaran Bahasa Arab Mahasiswa Lulusan Umum di Prodi PBA Jurusan Tarbiyah STAIN Jurai Siwo Metro 2016," An Nabighoh: Jurnal Pendidikan dan Pembelajaran Bahasa Arab 20, no. 02 (31 Desember 2018): 178-201, https://doi.org/10.32332/an-nabighoh.v20i02.1283.

${ }^{7}$ Sukarno, "Pengaruh Penggunaan Media Pembelajaran Terhadap Prestasi Belajar Pendidikan Agama Islam Siswa Kelas XI IPA SMA N 3 Semarang” (Skripsi, Semarang, UIN Walisongo, 2009), http://eprints.walisongo.ac.id/11342/.

${ }^{8}$ Ahmad Syarifuddin, "Penerapan Model Pembelajaran Cooperative Belajar Dan Faktor-Faktor Yang Mempengaruhinya," Ta'dib: Jurnal Pendidikan Islam 16, no. 01 (2011): 113, http://jurnal.radenfatah.ac.id/index.php/tadib/article/view/57.
} 


\section{B. Studi Literatur}

\section{Konseptual Pengajaran Bahasa Arab}

Pengajaran bahasa Arab merupakan kegiatan mengajar yang dilakukan oleh seorang pendidik kepada peserta didik dengan materi tertentu agar supaya peserta didik dapat memahami materi yang diajarkan. Dengan kata lain proses pembelajaran merupakan usaha yang dilakukan oleh seorang pendidik dalam menciptakan kegiatan belajar mengajar tentang salah satu materi tertentu yang kondusif dan efektif untuk mencapai tujuan. Dengan ini, pembelajaran bahasa Asing adalah kegiatan mendidik yang dilakukan secara efektif oleh seorang pendidik, agar peserta didik yang menerima materi bahasa Asing tertentu melakukan kegiatan belajar dengan baik, sehingga kondusif untuk mencapai tujuan belajar bahasa asing. ${ }^{9}$

Pengajaran berasal dari kata "ajar", yang setelah itu menjadi sebuah kata kerja dan tambahan kata yang menjadi berupa "pengajaran". Pengajaran sebenarnya adalah aspek atau sudut pandang kegiatan manusia yang singkat, hal tersebut tidak dapat semuanya dijelaskan dengan rinci. Makna yang lebih kompleks, hakikat dari pengajaran adalah upaya adanya seseorang pendidik untuk mengajarkan peserta didiknya dalam rangka mencapai tujuan yang diharapkan. ${ }^{10}$

Faktor yang mendukung proses pembelajaran bahasa Arab meliputi kemampuan peserta didik dan kemampuan seorang pendidik (sumber daya manusia) dalam mengajar, persiapan peserta didik dalam menerima materi, sarana dan prasarana yang mendukung, keberadaan lingkungan dan lainnya. ${ }^{11}$ Dengan demikian, pengajaran itu merupakan yang mana aspek kegiatan manusia yang membantu untuk memahamkan manusia lainnya yang secara kompleks. Penjelasan lainnya dalam pengajaran mempunyai cara yang mana cara itu untuk melakukan proses pengajarannya, serta yang didukung oleh beberapa faktor yang terkait di dalamnya.

Konsep dalam pembelajaran merupakan dasar utama bagi pendidik untuk melakukan proses pembelajaran. Supaya peserta didik mampu menguasai materi yang dipelajari, terutama dalam mempelajari bahasa Arab dan tidak adanya kesulitan dalam komponen bahasa. Sebagaimana menurut

\footnotetext{
${ }^{9}$ Muhammad Wafaul Himam dan Raswan Raswan, "Tamyiz; Model Alternatif Pembelajaran Bahasa Arab Sebagai Bahasa Al-Qur'an," Lisan Al-Arab : Journal of Arabic Language And Arabic Teaching 6, no. 1 (2017): 18-28, https://journal.unnes.ac.id/sju/index.php/laa/article/view/14389.

${ }_{10}$ Jamil Suprihatiningrum, Strategi Pembelajaran Teori \& Aplikasi (Yogyakarta: ArRuzz Media, 2013), 73.

${ }^{11}$ Buhori Muslim, “Konsep Scientific Approach Dalam Pembelajaran Bahasa Arab Di Perguruan Tinggi (Upaya Meningkatkan Produktivitas, Kreativitas Dan Inovasi Mahasiswa Dalam Pembelajaran)," LISANUNA: Jurnal IImu Bahasa Arab dan Pembelajarannya 5, no. 1 (2016): 105, https://jurnal.ar-raniry.ac.id/index.php/lisanuna/article/view/858.
} 
Ely yang telah dikutip oleh Sanjaya mengatakan bahwa pembelajaran adalah dasar suatu proses dan cara berpikir pendidik untuk membantu kelancaran pembelajaran, sehingga dapat menciptakan hasil yang diharapkan pendidik. ${ }^{12}$

Selain itu pengajaran mempunyai beberapa langkah yang harus dilalui oleh peserta didik dan pendidik, supaya pengajaran dapat berjalan dengan baik. Langkah paling umum yang dilalui oleh peserta didik adalah pemahaman terhadap empat maharah (linguistik) dalam proses pembelajaran bahasa Arab yaitu, istima', kalam, qira'ah, dan kitabah. Dari keempat maharah tersebut merupakan satu kesatuan komponen yang tidak dapat dipisahkan dan saling berkaitan. Dalam penerapan pengajaran kepada peserta didik, seorang pendidik juga mempersiapkan sebagaimana materi yang akan digunakan dalam proses berlangsungnya pembelajaran tersebut. ${ }^{13}$

Selain itu juga menyiapkan media atau sarana dan prasarana yang akan digunakan dalam proses pembelajaran itu sendiri. Dan juga memberikan evaluasi kepada peserta didik sebagai tolak ukur pemahaman dan keberhasilan peserta didik. ${ }^{14}$ Artinya seorang pendidik sebelum memulai proses pembelajaran harus menyiapkan dan menguasai materi yang akan diajarkan kepada peserta didik. ${ }^{15}$

Selain dari langkah-langkah dalam pengajaran bahasa Arab, ada juga beberapa faktor yang mempengaruhi peserta didik dalam menempuh proses pembelajaran atau pengajaran, yaitu faktor yang berada di dalam atau faktor internal. Dalam faktor internal terdapat juga pembagian suatu yang mempengaruhi dalam berlangsungnya pengajaran. ${ }^{16}$ Faktor tersebut meliputi kesehatan dalam tubuh dan kesehatan pemikiran (psikologis), yang mana dalam hal ini harus keadaan sehat dan tidak ada hal sedikit pun yang berkurang dalam kesehatan. Dalam kesehatan lainnya juga diperlukan seperti kesehatan dalam pemikiran dan tidak dalam gangguan pemikiran. ${ }^{17}$

\footnotetext{
12 Wahyudin Nur Nasution, “Perencanaan Pembelajaran: Pengertian, Tujuan Dan Prosedur," ITTIHAD 1, no. 2 (2017), http://ejournalittihad.alittihadiyahsumut.or.id/index.php/ittihad/article/view/23.

${ }^{13}$ Rahmaini, Strategi Pembelajaran Bahasa Arab Aktif dan Menarik (Medan: Perdana, 2015), http://repository.uinsu.ac.id/2452/.

${ }^{14}$ Sembodo Ardi Widodo, "Model-Model Pembelajaran Bahasa Arab," Al-Arabiyah Jurnal Pendidikan Bahasa Arab 2, no. 2 (2006), http://digilib.uin-suka.ac.id/7957/.

${ }^{15}$ Anwar Abd Rahman, "Pengajaran Bahasa Arab Dengan Metode Eklektik," Jurnal Adabiyah 11, no. 1 (2011): 65-74, http://journal.uinalauddin.ac.id/index.php/adabiyah/article/view/2801.

${ }^{16}$ Burhanuddin Abdullah, Radiansyah Radiansyah, dan Ali Akbar, "Pendidikan Karakter Di Madrasah Aliyah Negeri (MAN) 2 Banjarmasin," INFERENSI: Jurnal Penelitian Sosial Keagamaan 9, no. 2 (2015): 537, https://doi.org/10.18326/infsl3.v9i2.537-560.

${ }^{17}$ Nursyaidah, "Faktor-Faktor Yang Mempengaruhi Belajar Peserta Didik," FORUM PAEDAGOGIK 6, no. 3 (2014), http://jurnal.iainpadangsidimpuan.ac.id/index.php/JP/article/view/446.
} 
Selain dari faktor internal ada juga faktor dari luar yang mempengaruhi pengajaran terhadap peserta didik, seperti motivasi dari guru, keluarga, lingkungan sekitar, minat peserta didik, masyarakat dan lain sebagainya. ${ }^{18}$ Selain itu banyak faktor yang mempengaruhi minat seorang peserta didik dalam mempelajari bahasa Arab. Saat melakukan proses pembelajaran atau pengajaran guru atau pendidik menggunakan suatu metode supaya dapat menyampaikan materi dengan baik kepada peserta didik. ${ }^{19}$ Tetapi suatu metode juga mempunyai kekurangan dan kelebihan dalam suatu pengajaran bahasa, misalnya kurangnya sarana dan prasarana pendidik, metode yang digunakan kurang efektif dan lain sebagainya.

\section{Problematika Pengajaran Bahasa Arab}

Pada abad ke-17 proses pembelajaran bahasa Arab dimulai, yang mana pada kali pertama pengajaran bahasa Arab dimulai di salah satu Universitas Cambridge Inggris. Dalam pengajaran bahasa Arab tentunya tidak semudah yang dilihat orang yang mana di dalam proses pembelajaran itu mempunyai masalah-masalah yang harus dilalui oleh peserta didik di sana. Salah satunya adalah masalah atau problem pemahaman tentang linguistik. Problematika mempunyai sebuah arti yang mana disebut juga sebagai masalah atau problema, yang mana dalam bahasa Inggris disebut juga "Problematic", sedangkan dalam bahasa Indonesia diartikan sebagai suatu permasalahan yang belum terselesaikan atau sesuatu yang menimbulkan masalah.

Dalam pemahaman lain problematika adalah suatu masalah yang timbul dan dilalui oleh seseorang untuk mencapai tujuan yang diinginkan, khususnya juga suatu masalah seorang pendidik dan peserta didik dalam mempelajari bahasa Arab. Problematika pengajaran bahasa Arab meliputi kesulitan yang dialami oleh peserta didik dalam proses belajarnya yang dikarenakan sifat bahasa itu sendiri yang khusus dalam bahasa asing. Kesulitan yang dialami peserta didik tidak lepas dari beberapa komponen linguistik dari bahasa itu sendiri. ${ }^{20}$

Selain itu pengajaran mempunyai beberapa langkah yang harus dilalui oleh peserta didik dan pendidik, supaya pengajaran dapat berjalan dengan baik. Langkah paling umum yang dilalui oleh peserta didik adalah pemahaman terhadap empat maharah (linguistik) dalam proses pembelajaran bahasa Arab yaitu, istima', kalam, qira'ah, dan kitabah. Dari keempat maharah tersebut merupakan satu kesatuan komponen yang tidak dapat

\footnotetext{
${ }^{18}$ Firman, "Analisis Data dalam Penelitian Kualitatif," 1 November 2018, https://www.researchgate.net/publication/328675958_Analisis_Data_dalam_Penelitian_K ualitatif.

${ }^{19}$ Sugiyono, Metode Penelitian Kuantitatif, Kualitatif dan $R \& D$ (Bandung: Alfabeta, 2015), 31.

${ }^{20}$ Liliana Muliastuti, “Linguistik Umum,” dalam Bahasa Dan Linguistik, vol. 1 (Jakarta: Universitas Terbuka, 2014), 1-42, http://repository.ut.ac.id/4729/.
} 
dipisahkan dan saling berkaitan. Dalam penerapan pengajaran kepada peserta didik, seorang pendidik juga mempersiapkan sebagaimana materi yang akan diinginkan dalam proses berlangsungnya pembelajaran tersebut. ${ }^{21}$

Masalah kebahasaan merupakan peserta didik yang dihadapkan dengan persoalan-persoalan atau pembelajaran yang berkaitan langsung dengan bahasa yang sedang dipelajari. Problematika pembelajaran bahasa Arab yang pada umumnya dialami oleh peserta didik adalah problematika bunyi bahasa Arab. Tata bunyi merupakan salah satu komponen dari linguistik yang pola bunyi dan konsonannya yang berbeda antara bahasa Arab dan bahasa Indonesia. Terjadinya suatu perubahan suatu makna yang mana peletakan suatu kata yang berbeda. Problematika pengajaran kosakata yang memiliki banyak arti. Kosakata memiliki sangatlah fleksibel, yang seharusnya dapat dipahami oleh peserta didik. Problematika dalam kosakata ini terletak pada suatu pembagian wazan dan sighotnya. Problematika penulisan bahasa Arab terletak dimana huruf dalam bahasa Arab yang hampir sama dengan huruf satu dengan huruf yang lainnya. Hanya saja dalam perbedaannya ditandai dengan titik yang terletak pada huruf itu sendiri.

Selain itu pola penulisan dalam bahasa Arab dimulai dari sebelah kanan yang membuat peserta didik kurang nyaman dan menjadi hambatan dalam penulisan. Problematika tata bahasa sulit dipahami oleh peserta didik bagaimana maksud dan tujuan dari tulisan tersebut. Dari beberapa hal tersebut, maka problematika linguistik yang pada umumnya menjadi kendala oleh peserta didik dalam mempelajari bahasa Asing terutama bahasa Arab. Selain itu ada juga problematika yang sifatnya non linguistik seperti motivasi, sumber daya peserta didik yang kurang memahami, profesionalisme seorang pendidik, media yang digunakan, fasilitas, materi yang diajarkan dan metode yang digunakan oleh seorang pendidik.

\section{Metode Penelitian}

Penelitian ini menganalisa problematika pengajaran bahasa Arab. Tempat penelitian ini di Madrasah Aliyah Raudlatul Hidayah Ma'arif Nahdlatul Ulama 03 Mengandungsari, pemilihan lokasi penelitian didasarkan atas pertimbangan bahwa madrasah ini memiliki keunggulan guru yang sudah baik, sarana dan prasarana yang baik tetapi tentang pembelajaran yang berkurang.

Penelitian kualitatif merupakan jenis penelitian lapangan (field research) dengan pendekatan deskriptif kualitatif. Penelitian ini mengambil sumber data yang benar-benar asli dan alamiah dari apa yang terjadi. Dengan pengamatan langsung oleh peneliti sebagai alat utama penelitian dengan menggunakan melihat langsung proses terjadinya pembelajaran dan

\footnotetext{
${ }^{21}$ Rahmaini, Strategi Pembelajaran Bahasa Arab Aktif dan Menarik.
} 
menggunakan teknik wawancara. Penelitian ini mementingkan suatu proses pembelajaran dari pada hasil dari pembelajaran yang menyangkut variabel yang mempengaruhi satu dengan lainnya. Penelitian ini merupakan penelitian kualitatif yang mempunyai ciri yang berbeda dengan yang lainnya.

Metode pengumpulan data dalam penelitian ini menggunakan metode observasi, wawancara dan dokumentasi dari sekolah. Metode observasi merupakan pengamatan secara langsung di lapangan atau pencatatan fenomena dan peristiwa yang terjadi di lapangan saat proses penelitian berlangsung. Dalam metode ini peneliti mengumpulkan data dengan cara melihat langsung peristiwa yang terjadi saat itu. Metode wawancara merupakan metode yang digunakan penelitian kualitatif yang mana berfungsi sebagai alat pengumpulan data dengan cara tanya jawab terhadap subjek tertentu atau kepada responden yang berkaitan. Sedangkan metode dokumentasi merupakan metode yang berguna untuk pengumpulan data dengan gambar, tertulis atau media visual. Seperti halnya terdapat di bukubuku, surat kabar radio catatan dan arsip dari tempat penelitian. Sedangkan analisis data pada penelitian ini menggunakan analisis deskriptif, yang mana bertujuan untuk mengetahui informasi yang berada di lapangan tentang keadaan subjek-subjek yang ada. Analisis data merupakan alat yang digunakan untuk pengorganisasian dan mengurutkan data secara valid. Agar pembaca dapat memahami dan bisa menggambarkan secara sistematis penelitian tentang fakta yang akurat yang berada di lapangan. Penelitian ini merupakan penelitian yang mengambil sumber data langsung di lapangan dan wawancara terhadap subjek yang bersangkutan.

Instrumen dalam pengumpulan data pada penelitian ini menggunakan berupa data yang telah didapat dari dokumentasi sekolah dan peneliti ikut serta dalam proses pembelajaran berlangsung. Sehingga dapat mengetahui secara valid dan jelas ketika mengumpulkan data. Baik dalam cara pemahaman peserta didik, pemberian materi pendidik kepada peserta didik, media yang digunakan sampai cara pengelolaan kelas seorang pendidik.

\section{Hasil Penelitian}

\section{Problematika pengajaran bahasa Arab di Madrasah Aliyah}

Problema linguistik dan problema non linguistik merupakan problema yang umumnya dialami oleh peserta didik saat proses pembelajaran berlangsung. Dalam pengajaran kebahasaan khususnya pengajaran terhadap bahasa Arab memerlukan ketanggapan peserta didik saat proses pembelajaran berlangsung. Serta metode yang diterapkan oleh seorang pendidik harus sesuai dengan situasi dan kondisi kemampuan peserta didik. Pengajaran bahasa Arab pada umumnya peserta didik mengalami hambatan dalam pemahaman materi. Problema pengajaran bahasa Arab di Madrasah Aliyah Raudaltul Hidayah Ma'arif Nahdlatul Ulama 03 Mengandungsari 
memiliki dua problema yang dialami oleh peserta didik, yaitu problematika linguistik dan problematika non linguistik. Pada problema ini guru dituntut untuk bisa mengatasi atau setidaknya meminimalisir problema yang dialami oleh peserta didik. Problematika linguistik atau problema ilmu kebahasaan meliputi bunyi, kosakata dan tata bahasa atau qowaid.

Adapun problematika linguistik dalam konteks bunyi (ashwat) yang dialami oleh peserta didik berlatar belakang kurangnya pemahaman tentang pembelajaran bahasa Arab dan kandungan unsur dalam bahasa Arab. Peserta didik dituntut untuk menyetarakan dengan temannya yang sudah mampu menerima pemahaman yang diperoleh. Problematika dalam konteks bunyi di Madrasah Aliyah sudah menjadi problema yang belum bisa diminimalisir oleh pendidik, rata-rata peserta didik di Madrasah kurang mampu menguasai materi dengan faktor yang mempengaruhinya. Peserta didik mampu mendengar yang dibicarakan atau yang dibacakan oleh seorang pendidik di dalam kelas saat proses pembelajaran berlangsung, dari hal tersebut akan dimulai problema oleh peserta didik, terutama peserta didik yang belum bisa memahami ucapan dari pendidik. Sebelum proses pembelajaran berlangsung peserta didik dibagikan buku materi yang akan disimak. Tetapi dalam hal ini masalah timbul karena peserta didik hanya mampu mendengar tapi tidak bisa memahami apa yang telah didengar.

Pembelajaran kosakata atau mufrodat di Madrasah Aliyah juga mengalami problema yang serius, dalam hal ini peserta didik kurang mampu dan kurang memahami kosakata yang baru. Karena dalam pembelajaran bahasa Arab di Madrasah yang seharusnya peserta didik semangat belajar bahasa Arab dan memahami kosakata terhambat oleh problematika yang ada di Madrasah Aliyah. Peserta didik yang kurang menguasai materi yang disampaikan dan pendidik yang kurang mampu menguasai materi atau kurang menghidupkan suasana kelas yang baik. Pengajaran kosakata kepada peserta didik yang mana pendidik harus mampu menggunakan metode yang tepat, karena kosakata merupakan salah satu dasar komponen untuk pemahaman bahasa Arab kedepannya bagi peserta didik.

Problematika tata bahasa atau problematika qowaid yang dialami oleh peserta didik di sekolah Madrasah Aliyah Raudaltul Hidayah Ma'arif Nahdlatul Ulama 03 Mengandungsari mengalami problema serius yang dialami oleh peserta didik maupun pendidik ketika akan menyampaikan materi kepada peserta didik. Tata bahasa merupakan salah satu problema yang sangat banyak dialami oleh peserta didik di sekolah-sekolah manapun, karena tata bahasa Arab harus mengetahui rumus dan kunci untuk memahami ilmu tersebut. Seperti nahwu dan shorof yang merupakan kunci dari pemahaman tata bahasa arab. Madrasah Aliyah Raudaltul Hidayah Ma'arif Nahdlatul Ulama 03 Mengandungsari rata-rata peserta didiknya bukan dari pondok pesantren, yang latar belakangnya tidak pernah 
mempelajari nahwu dan shorof. Adapun yang berada di pondok pesantren itu pun belum tentu dapat memahami secara maksimal tentang tata bahasa Arab.

Linguistik merupakan ilmu yang mempelajari tentang kebahasaan secara menyeluruh. Peserta didik diwajibkan mengetahui dan memahami tentang linguistik. Tetapi pada realitanya peserta didik banyak yang mengalami kesulitan dan hambatan. Peserta didik di Madrasah Aliyah Raudaltul Hidayah Ma'arif Nahdlatul Ulama 03 Mengandungsari mengalami hambatan yang serius dalam mempelajari tentang linguistik.

Selain problematika itu, ada juga problematika yang membuat peserta didik mengalami hambatan seperti problematika qiro'ah, istima', kitabah, dan kalam. Peserta didik mengalami problema qiro'ah sekitar 40-50 persen. Sebagian peserta didik sudah mampu menguasai walau tidak sempurna, karena dari latar belakang yang mampu membaca huruf Arab. Problema istima' yang dialami peserta didik kurangnya pemahaman tentang apa yang didengar baik dari pendidik maupun teman sekelasnya membacakan teks atau berbicara dengan bahasa Arab. Problematika kitabah pada peserta didik di Madrasah Aliyah Raudaltul Hidayah Ma'arif Nahdlatul Ulama 03 Mengandungsari mengalami kesusahan dan hambatan tentang menulis bahasa Arab.

Dalam wawancara peneliti terhadap peserta didik tentang kesulitan menulis bahasa Arab yaitu tidaknya terbiasa menulis dari sebelah kanan yang membuatnya rikuh dan kurangnya nyaman dalam menulis. Problematika kalam pada peserta didik merupakan problematika besar kedua yang mana setelah tata bahasa. Yang mana peserta didik mengalami kesusahan dalam mengucapkan kosakata bahasa Arab karena tidak terbiasa dan sering menggunakan bahasa daerah masing-masing atau juga menggunakan bahasa Indonesia baik di dalam kelas, lingkungan sekolah dan di lingkungan masyarakat. Problema linguistik inilah yang sampai saat ini menjadi momok bagi para peserta didik saat proses pembelajaran bahasa Arab.

Problematika linguistik merupakan problema problematika individu bagi para peserta didik tentang kurangnya pemahaman terhadap komponenkomponen dalam ilmu kebahasaan, inilah yang masih melekat dalam peserta didik ketika mempelajari ilmu kebahasaan. Selanjutnya problema yang dialami oleh peserta didik adalah problematika non linguistik. Problema non linguistik timbul ketika pendidik kurang mampu dalam penguasaan materi saat pembelajaran berlangsung atau penggunaan metode yang kurang relevan, sehingga peserta didik mengalami kesusahan dalam memahami materi yang telah diberikan. Selain itu seorang pendidik kurang memberi motivasi terhadap peserta didik yang khususnya peserta didik tidak mampu menerima materi bahasa Arab. Madrasah Aliyah Raudaltul Hidayah Ma'arif Nahdlatul Ulama 03 Mengandungsari pendidiknya sudah mempunyai 
kemampuan yang sudah baik dalam mengajar, tetapi mereka kurang mampu memberikan pemahaman terhadap peserta didik.

Seorang pendidik menyampaikan materi kebahasaan kepada peserta didik yang mempunyai kemampuan baik maka langsung bisa memahami, tapi juga peserta didik yang bisa paham dengan pemahaman yang cukup lama. Peserta didik yang tidak paham mereka tidak memperhatikan materi yang disampaikan oleh pendidik. Problematika non linguistik ini merupakan momok kedua yang menjadi penghambat bagi peserta didik untuk gagal paham tentang materi yang diajarkan oleh pendidik. Madrasah ini mempunyai mutu pendidik yang baik dan sarana dan prasarana yang sudah cukup baik di tingkat Madrasah Aliyah. Tetapi cara penyampaian seorang pendidik yang menjadi penghambat dan problema non linguistik. Metode yang digunakan seorang pendidik sangat monoton dan kurang menarik perhatian peserta didik. Sehingga peserta didik mengalami kesusahan dan hambatan saat proses pembelajaran berlangsung. Seorang pendidik yang kurang mampu menghidupkan suasana kelas, menjadikan peserta didik malas dan mengantuk saat penyampaian materi. Strategi yang digunakan pendidik kurang tepat dan membuat peserta didik kurang minat terhadap pembelajarannya. Dalam proses pembelajarannya peserta didik diam bukan memahami atau menyimak, tetapi terpaku dengan penjelasan yang menyulitkan sehingga membuat peserta didik malas untuk memahami.

Proses pertama pendidik menyiapkan materi yang akan diajarkan dan merancangnya sesuai dengan metode yang sudah direncanakan. Proses pembelajaran dilakukan dengan memulai standar pembelajaran seperti biasa, yaitu pembukaan salam dan memulai doa sebelum melakukan pembelajaran. Setelah itu proses pembelajaran dilakukan penyampaian materi dengan cara penyampaian yang sama setiap pertemuan sebelumnya baik dengan kelas satu dengan kelas yang lainnya.

Dari proses pembelajaran itu kurangnya tentang pengetahuan dan penguasaan materi seorang pendidik sehingga peserta didik hanya mampu memahami mufrodat, tetapi semua itu kurang optimal dalam pembelajaran karena dari mufrodat itu juga belum selalu paham tentang penggunaannya. Pendidik kurang mampu menghidupkan suasana kelas yang mana di dalam kelas kurang efektif saat proses pembelajaran, sehingga peserta didik kurang memperhatikan saat pembelajaran berlangsung. Seorang pendidik seharusnya bisa menghidupkan suasana kelas dan mampu mengendalikan peserta didik saat mata pelajaran berlangsung.

Metode yang digunakan oleh seorang pendidik kurang efektif, mulai dari penggunaan media dan sarana prasarana yang tidak maksimal. Pendidik hanya fokus menerjemahkan teks bahasa Arab dan tidak menjelaskan kepada peserta didik maksud dari teks tersebut. Peserta didik banyak yang tidak paham tentang materi yang telah disampaikan oleh pendidik. Dalam proses 
pembelajaran banyak siswa yang mengabaikan tentang pelajaran bahasa Arab. Dari sisi itulah peserta didik akan mulai tidak tertarik dengan bahasa Arab. Setelah itu, pendidik memberikan materi kepada peserta didik dengan minimnya penjelasan dan kemudian diberikan tugas kelas. Peserta didik yang sama sekali tidak paham dengan apa yang diajarkan oleh pendidik, hanya terdiam dan biasanya menyepelekan tugas dari pendidik sehingga menyebabkan peserta didik kurang mampu memahami materi yang diajarkan. Dari sisi lain pendekatan juga diperlukan seorang pendidik untuk mengetahui kesulitan dan problema yang dialami oleh peserta didik. Pendekatan merupakan hal penting untuk pemahaman materi yang akan diajarkan kepada peserta didik.

Dalam proses pembelajaran peserta didik memiliki jumlah 30 peserta didik. Setiap peserta didik mempunyai latar belakang yang berbeda-beda sehingga hal ini bisa juga menjadi hambatan dalam proses pembelajaran bahasa Arab. Peserta didik mempunyai penguasaan dan kemampuan tersendiri dari masing-masing mata pelajaran, ada yang paham dengan bahasa Arab dan ada sangat minim tentang bahasa Arab. Dari pengumpulan data ini banyak peserta didik yang kurang pemahaman tentang kebahasaan karena didasari latar belakang yang kurang mendukung.

Pengambilan data ini dilakukan pada sekolah Madrasah Aliyah kelas XI yang mana peserta didik dan pendidiknya mengalami hambatan saat proses pembelajaran berlangsung. Peserta didik yang kurang paham tentang bahasa Arab ditambah dengan cara penyampaian materi pendidik yang kurang mendukung serta strategi yang tidak baik dengan kepribadian dan kesetaraan peserta didik, sehingga menjadi hambatan bagi para peserta didik untuk melakukan pemahaman terhadap materi kebahasaan dan kurang kolaborasi antara peserta didik dan pendidik. Problema non linguistik selain dari pendidik juga timbul dari peserta didik, dimana peserta didik masih berkaitan dengan tingkah laku, akhlak dan faktor dari lingkungan sekolah maupun sosial. Seorang pendidik yang sangat berkaitan dengan keteladanan karakter peserta didik, akan mempengaruhi problema pembelajaran.

Kebiasaan seorang pendidik merupakan yang perlu dicontohkan kepada peserta didik, karena peserta didik cenderung dengan cara meniru untuk perilaku dan karakter sehari-hari terutama di lingkungan sekolah. Kedisiplinan peserta didik sangat mempengaruhi proses pembelajaran, karena disiplin dalam belajar akan menimbulkan suatu semangat dalam belajar baik di dalam kelas maupun di luar kelas dan di lingkungan sekitar. Di Madrasah Aliyah memiliki kedisiplinan yang sangat kuat baik dalam pembelajaran bahasa Arab maupun pembelajaran lainnya. Peserta didik antusias dan semangat dalam mengikuti proses pembelajaran, tetapi masih ada yang belum paham dengan materi yang diajarkan oleh peserta didik. Sehingga akan menimbulkan masalah dan problema saat pemahaman bahasa 
Arab. Keteladanan seorang pendidik yang menjadi harapan bagi peserta didik. Setiap peserta didik akan meniru apa yang dilakukan pendidik yang sifatnya baik dan memotivasi bagi peserta didik. Pengawasan suatu kelakuan yang membantu dalam pelaksanaan teladan, kebiasaan dan kedisiplinan bagi peserta didik. Peraturan dan larangan akan berjalan dengan baik jika diawasi dengan baik pula secara terus menerus. Pengawasan adalah upaya menjaga suatu perbuatan agar dilakukan dengan baik serta mengamati perkembangan dalam menaati peraturan. Memerhatikan dan kepedulian kepada sesama teman satu kelas atau saling tolong menolong agar dapat melakukan pembelajaran dengan baik. Selain itu peserta didik juga perlu nasihat dari pendidik baik dalam pengajaran maupun di luar pengajaran. Seperti nasihat tentang akhlak kelakuan dan lain sebagainya. Peserta didik akan berkembang dalam pembelajarannya jika akhlak yang peserta didik gunakan baik di dalam maupun di luar pembelajaran.

Pengajaran bahasa Arab sudah lama diajarkan di Indonesia baik dari sekolah menengah sampai dengan perguruan tinggi. Pengajaran bahasa Arab pasti menemukan problema yang dialami oleh peserta didiknya atau orang yang mempelajari bahasa. Proses pengajaran bahasa Arab mengalami problema yang terus menerus sampai sekarang, pengajaran bahasa Arab menyangkut keberhasilan pembelajaran serta yang masih jauh dengan tujuan. Paling tidak problema yang kita temui dalam pengajaran bahasa Arab yaitu problematika linguistik dan problematika non linguistik. Problema tersebut masih menjadi masalah besar yang perlu diminimalisir, sehingga apa yang diharapkan dalam pengajaran bahasa Arab akan tercapai dari batas minimal.

Dalam mengatasi problematika pengajaran bahasa Arab di Madrasah Aliyah perlu adanya kesadaran bagi peserta didik untuk semakin memperbanyak pembelajaran bahasa Arab baik di sekolah ataupun di luar sekolah. Peningkatan mutu peserta didik dalam mempelajari bahasa Arab melibatkan proses pendidikan seorang pendidik yang telah membimbing dan membina peserta didik. Namun, pendidik akan berhasil jika didukung oleh peserta didik. Motivasi seorang pendidik sangat penting dalam pembelajaran, sehingga akan menjadikan peserta didik semangat dalam melakukan pembelajaran bahasa Arab. Mencoba metode yang baru oleh pendidik, sehingga bisa menciptakan suasana kelas yang aktif dan efektif dalam proses pengajaran. Dengan menggunakan metode yang baru otomatis dalam strategi pembelajarannya akan baru, agar supaya peserta didik dapat memahami materi yang telah disampaikan oleh pendidik. Memanfaatkan media yang ada, seperti smartphone untuk kelancaran dalam memahami bahasa Arab. Bisa mengulang kembali materi yang telah disampaikan pendidik jika dalam proses pembelajaran bahasa Arab lupa ataupun utuh bahan belajar di rumah. Penelitian ini merupakan penelitian yang mengambil sumber data langsung di lapangan dan wawancara terhadap subjek yang bersangkutan. 


\section{E. Pembahasan}

Problema linguistik merupakan problema yang sangat berpengaruh dalam proses pembelajaran peserta didik. Linguistik merupakan seperangkat software pada peserta didik saat pembelajaran berlangsung. Pembelajaran yang menyangkut software pada kenyataannya mengalami problema yang serius terhadap peserta didik. Problema dapat diketahui dengan meneliti secara langsung atau menggali sumber data yang relevan terhadap subjek yang bersangkutan. Problema linguistik atau problema software timbul dengan kurangnya pemahaman peserta didik terhadap karakter dari bahasa itu sendiri sebagai bahasa Asing. Problema yang dialami saat pembelajaran kurangnya pemahaman materi pembelajaran beserta komponen-komponen pembelajaran. Problematika yang muncul dari peserta didik dalam proses pembelajaran bahasa Arab adalah latar belakang yang tidak mampu menguasai bahasa Arab secara sempurna baik komunikasi dan gramatikalnya. Problema linguistik diantaranya adalah ashwat (bunyi bahasa), mufrodat (kosakata), dan qowaid/nahwu/tarkib (tata bahasa).

Problematika bunyi merupakan unit dari bahasa Arab yang memiliki berbagai macam sifat pengucapan yang berada, masing-masing pengucapannya memiliki karakteristik lain seperti halnya pengucapan makhrijul huruf atau keluarnya huruf, pengucapan yang susah. Dalam huruf bahasa Arab tidak semua ada dalam kategori huruf bahasa Indonesia seperti bunyi huruf $P$ yang diucapkan menjadi bunyi huruf $B$, bunyi huruf $G$ diucapkan menjadi bunyi huruf Ghin atau Jim, dan bunyi-bunyi lainnya. Gambaran dan pemahaman bahasa atas metode itu tidak sempurna dan tidak mencangkup seluruhan aspek kebahasaan, karena pada dasarnya bahasa merupakan tekanan bagi peserta didik yang mengandung ungkapan bagi setiap manusia. Bahkan di desa-desa pun sudah diajarkan tata bunyi bahasa Arab dalam ilmu tajwid. Pengajaran yang itu difokuskan untuk kemahiran dalam membaca Al-Qur'an dan tidak di kembangkan dalam ilmu kebahasaan atau pengembangan keterampilan berbahasa Arab. Tata bunyi yang selama ini dipelajari kurang mendapat kepedulian dalam mempelajari bahasa Arab. Mengakibatkan peserta didik kurang memahami ucapkan orang lain, bahkan tidak bisa dalam pengucapan. Selanjutnya akan menimbulkan problema pada penulisan bahasa Arab.

Problematika kosakata yang mana juga menjadi penghambat bagi para peserta didik dalam mempelajari bahasa Arab. Tetapi ada faktor yang menjadi keuntungan bagi para peserta didik dan pendidik dalam mempelajari bahasa Arab, yang mana bahasa Arab dapat ditemukan dalam bahasa persamaan di bahasa Indonesia dan di bahasa daerah. Dalam peralihan bahasa Asing, kebahasaan peserta didik menimbulkan problema pergeseran makna, perubahan lafadz yang bunyinya berbeda dengan aslinya dan lafadznya sama tetapi artinya yang berubah sesuai konteks pembahasan. 
Dengan problem tersebut peserta didik akan merasa kesusahan dalam mempelajari bahasa Arab secara maksimal. Peserta didik cenderung hanya memahami bahwa bahasa Arab adalah pembelajaran dasar tentang ungkapan sehari-hari dan berupa mata pelajaran saja.

Pengajaran tata bahasa Arab merupakan proses pembelajaran yang penting untuk peserta didik di sekolah-sekolah madrasah dan sekolah umum lainnya yang memperhatikan pembelajaran bahasa Arab. Problema yang dialami oleh peserta didik yang bersangkutan dengan gramatika tata bahasa Arab atau aturan-aturan qowaid yang menghubungkan satu kata dengan kata lainnya sebagai pernyataan struktur kalimat dan gagasan serta problema lainnya yang dialami saat penyusunan kosakata dan memperhatikan rumus tata bahasa dalam bahasa Arab. Penyusunan tata bahasa Arab membutuhkan keterampilan peserta didik dalam memahami dan mengingat tentang rumusrumus yang telah menjadi aturan tata bahasa Arab. Problema tata bahasa Arab merupakan problema yang banyak dikeluhkan oleh peserta didik di tingkat sekolah menengah sampai di perguruan tinggi pun banyak yang memiliki problema yang sama bahkan seorang pendidik pun juga mengalami problema tentang tata bahasa, baik secara pembelajaran, materi dan penyampaian materi kepada peserta didik.

Problematika penulisan dalam bahasa Arab juga dikeluhkan oleh peserta didik dalam proses pembelajaran, karena dasar dan karakter peserta didik yang kurang mampu memahami tentang tulisan bahasa Arab. Kurangnya pemahaman peserta didik dengan tulisan, maka akan timbul problema yang berkaitan dengan problema tata bunyi bahasa Arab. Keluhan peserta didik terhadap problema kitabah atau menulis ini beragam, seperti halnya persamaan huruf dalam bahasa Arab dan hanya dibedakan dengan titik dan sistem penulisan yang berawal dari sebelah kanan ke kiri. Problema dari kitabah ini ditimbulkan karena penulisan bahasa Arab yang berbeda dengan penulisan bahasa Indonesia dan bahasa-bahasa lainnya (tulisan latin). Tidak heran jika peserta didik melakukan kesalahan dalam penulisan bahasa Arab baik dari huruf yang hampir sama penyebutannya bahkan tidak heran pula yang sudah duduk di bangku kuliah akan mengalami kesalahan dalam penulisan bahasa Arab, terutama dalam penulisan Al-Qur'an hadis serta penulisan lainnya yang berkaitan dengan bahasa Arab.

Morfologi merupakan pembelajaran tentang bentuk suatu kalimat (kata) yang berupa perubahan suatu bentuk kata atau sighat. Morfologi juga merupakan problema yang dialami peserta didik karena dalam pola perubahan bentuk kata yang sangat sulit dan perlu pemahaman. Problema tentang morfologi memerlukan waktu yang lama karena pemahaman suatu kaidah yang terbagi dalam berbagai bab. Morfologi yang masih berkaitan dengan tata bahasa (nahwu) memiliki kajian yang sama dalam pengajaran bahasa Arab, kajian dalam morfologi juga merupakan kajian di dalam nahwu 
dan begitupun sebaliknya. Maka akan membuat bingung peserta didik dalam memahami morfologi. Selain itu problema morfologi juga ada kaitannya dengan problema tata bunyi. Bahasa mempunyai ciri khas dan keistimewaan masing-masing, terutama bahasa Arab yang memiliki kandungan jutaan ilmu yang berada di dalamnya. Maka dalam sekolah menengah sampai perguruan tinggi mempelajari bahasa Arab. Dari pembelajaran bahasa Arab mempunyai berbagai masalah dan problema yang dialami oleh peserta didik, khususnya morfologi merupakan problema yang dikeluhkan oleh peserta didik karena dengan rumus yang harus dipahami dan dihafal.

Morfologi ini sangat erat dengan memperhatikan bentuk kalimat maka dengan sintaksis ini adalah ilmu yang mempelajari nahwu yang problematikanya tidak seberat yang dialami morfologi. Tetapi peserta didik juga pasti akan mengalami kesulitan untuk mempelajari sintaksis atau gramatikal ini. Problema gramatikal ini digolongkan lebih ringan dari problema sebelumnya, problema yang dialami peserta didik pada umumnya adalah susah untuk mengetahui bentuk kalimat dalam bahasa Arab dari bentuk jumlah yang diajarkan kepada peserta didik dengan bahasa Asing lainnya yang diajarkan. Rumus-rumus dan tata bahasa Arab yang tidak akan ditemukan di dalam bahasa Asing lainnya, hal inilah yang memberi hal lain dalam bahasa Arab.

Problematika non linguistik yang mana pada kali ini diakibatkan dari luar atau hardware dari bahasa itu sendiri, akan tetapi masih berpengaruh di dalam proses pembelajaran. Seorang pendidik yang kurangnya pemahaman terhadap penggunaan dan penyampaian materi oleh seorang pendidik kepada peserta didik, sehingga kurang optimal dalam pembelajaran.

Problematika linguistik merupakan problema yang muncul dari dalam struktur zat bahasa itu sendiri. Sedangkan selain dari problematika linguistik, problema non linguistik juga merupakan suatu hambatan dan problema bagi peserta didik dalam pengajaran bahasa Arab. Problema non linguistik ini merupakan problema yang timbul dari luar komponen bahasa itu atau masalah yang timbul di luar materi bahasa itu sendiri. Seorang pendidik dalam melakukan proses pengajaran yang kurang baik, tidak memiliki keterampilan dan kompetensi sebagai pendidik bahasa Arab, baik dari segi profesionalisme seorang pendidik, komunikasi sosial, pedagogi, dan masalah lain yang menyangkut pendidik tidak mampu menyampaikan materi dengan baik. Selain dari seorang pendidik problema ini juga timbul dari peserta didik, materi ajar dan sarana prasarana pengajaran. Peserta didik yang tidak mampu dalam untuk belajar bahasa Arab karena latar belakang yang tidak ada pemahaman dalam bahasa Arab, serta kurangnya motivasi peserta didik dalam mempelajari bahasa Arab. Sebelum melakukan proses pembelajaran, pendidik perlu ada strategi, metode dan bahan ajar atau bahan materi yang akan disampaikan kepada peserta didik. Materi yang akan diajarkan ini akan 
menjadi problema pembelajaran bahasa Arab jika materi yang diajarkan kurang relevan dengan keperluan peserta didik. Media merupakan alat untuk mempermudah proses pembelajaran bagi peserta didik di dunia. Dengan adanya media atau alat bantu untuk menambah ilmu kita akan dimudahkan dalam proses pembelajaran. Tetapi jika kurang efektif akan mengakibatkan problema terkhususnya dalam proses pembelajaran, yang seharusnya pembahasan yang sudah dibahas akan tertinggal dengan kurangnya media yang dimiliki. Dengan kurangnya sarana dan prasarana yang dimiliki akan menimbulkan problema dan masalah saat proses pembelajaran terutama dalam proses pembelajaran bahasa Arab.

Dari tahun ke tahun keluhan yang dialami oleh peserta didik sampai seorang pendidik tentang pengajaran bahasa Arab menyangkut keberhasilan pembelajaran serta yang masih jauh dengan tujuan dan harapan pembelajaran bahasa Arab. Semakin kita mempelajari ilmu bahasa maka akan semakin banyak pula tantangan untuk memahami bahasa itu sendiri. Problema akan muncul dan akan menjadi masalah bagi peserta didik yang perlu diminimalisir. Paling tidak ada dua problema utama yang dihadapi dan akan terus dihadapi yaitu problematika linguistik dan problematika non linguistik. Problema tersebut masih menjadi masalah besar yang perlu diminimalisir, sehingga apa yang diharapkan dalam pengajaran bahasa Arab akan tercapai dari batas minimal. Pembelajaran bahasa Arab dapat dipahami oleh peserta didik yang mempunyai semangat dalam mempelajari hal apapun.

\section{F. Kesimpulan}

Pengajaran bahasa Arab merupakan kegiatan belajar mengajar yang dilakukan oleh seorang mendidik dengan materi tertentu agar supaya dipahami oleh peserta didik. Pengajaran bahasa Arab di dunia khususnya di Indonesia mengalami banyak problema yang menjadikan peserta didik kesulitan untuk memahami pengajaran bahasa Arab. Problematika pengajaran bahasa Arab memiliki dua faktor utama yang menjadi kesulitan peserta didik dalam memahami bahasa Arab, yaitu problematika linguistik dan problematika non linguistik. Problematika linguistik merupakan problema yang bersumber dari dalam materi pengajaran atau dari komponenkomponen bahasa itu sendiri. Problematika linguistik yang sering dialami oleh peserta didik adalah tata bunyi bahasa Arab (ashwat), kosakata (mufrodat) dan tata bahasa Arab (qowaid/nahwu/tarkib). Sedangkan problematika non linguistik adalah problema yang berada di luar materi tetapi masih ada pada proses pembelajaran. Problematika non linguistik yang dialami oleh peserta didik adalah materi yang digunakan pendidik kurang relevan, sarana dan prasarana, motivasi yang kurang dari pendidik dan media yang digunakan kurang efisien. 


\section{Daftar Pustaka}

Abdullah, Burhanuddin, Radiansyah Radiansyah, dan Ali Akbar. "Pendidikan Karakter Di Madrasah Aliyah Negeri (MAN) 2 Banjarmasin." INFERENSI: Jurnal Penelitian Sosial Keagamaan 9, no. 2 (2015): 537. https://doi.org/10.18326/infsl3.v9i2.537-560.

Firman. "Analisis Data dalam Penelitian Kualitatif," 1 November 2018.

https://www.researchgate.net/publication/328675958_Analisis_Dat a_dalam_Penelitian_Kualitatif.

Hidayat, Nandang Sarip. "Problematika Pembelajaran Bahasa Arab." An-

Nida' 37, no. 1 (2012): 82-88. http://ejournal.uinsuska.ac.id/index.php/Anida/article/view/315.

Himam, Muhammad Wafaul, dan Raswan Raswan. "Tamyiz; Model Alternatif Pembelajaran Bahasa Arab Sebagai Bahasa Al-Qur'an." Lisan Al-Arab : Journal of Arabic Language And Arabic Teaching 6, no. 1 (2017): 18-28.

https://journal.unnes.ac.id/sju/index.php/laa/article/view/14389. Khoirurrijal, Khotijah, Ahmad Arifin, Ani Susilawati, dan Nawang Wulandari. Interpretasi Makna (Prosedur Penerjemahan Arab - Indonesia).

Yogyakarta: Idea Press, 2019.

Muliastuti, Liliana. "Linguistik Umum." Dalam Bahasa Dan Linguistik, 1:142. Jakarta: Universitas Terbuka, 2014.

http://repository.ut.ac.id/4729/.

Muslim, Buhori. "Konsep Scientific Approach Dalam Pembelajaran Bahasa Arab Di Perguruan Tinggi (Upaya Meningkatkan Produktivitas, Kreativitas Dan Inovasi Mahasiswa Dalam Pembelajaran)." LISANUNA: Jurnal Ilmu Bahasa Arab dan Pembelajarannya 5, no. 1 (2016): 105. https://jurnal.arraniry.ac.id/index.php/lisanuna/article/view/858.

Nasution, Wahyudin Nur. "Perencanaan Pembelajaran: Pengertian, Tujuan Dan Prosedur." ITTIHAD 1, no. 2 (2017). http://ejournalittihad.alittihadiyahsumut.or.id/index.php/ittihad/article/view/23. Nursyaidah. "Faktor-Faktor Yang Mempengaruhi Belajar Peserta Didik."

FORUM PAEDAGOGIK 6, no. 3 (2014). http://jurnal.iainpadangsidimpuan.ac.id/index.php/JP/article/view/446.

Pingge, Heronimus Delu, dan Muhammad Nur Wangid. "Faktor Yang

Mempengaruhi Hasil Belajar Siswa Sekolah Dasar Di Kecamatan Kota Tambolaka." Jurnal JPSD (Jurnal Pendidikan Sekolah Dasar) 2, no. 2 (2016): 107.

http://journal.uad.ac.id/index.php/JPSD/article/view/4947. 
Rahmaini. Strategi Pembelajaran Bahasa Arab Aktif dan Menarik. Medan: Perdana, 2015. http://repository.uinsu.ac.id/2452/.

Rahman, Anwar Abd. "Pengajaran Bahasa Arab Dengan Metode Eklektik." Jurnal Adabiyah 11, no. 1 (2011): 65-74. http://journal.uinalauddin.ac.id/index.php/adabiyah/article/view/2801.

Sarbaini, Albarra. "Problematika Pengajaran Bahasa Arab Mahasiswa Lulusan Umum di Prodi PBA Jurusan Tarbiyah STAIN Jurai Siwo Metro 2016." An Nabighoh: Jurnal Pendidikan dan Pembelajaran Bahasa Arab 20, no. 02 (31 Desember 2018): 178-201. https://doi.org/10.32332/an-nabighoh.v20i02.1283.

Sembodo Ardi Widodo. "Model-Model Pembelajaran Bahasa Arab." AlArabiyah Jurnal Pendidikan Bahasa Arab 2, no. 2 (2006). http://digilib.uin-suka.ac.id/7957/.

Sugiyono. Metode Penelitian Kuantitatif, Kualitatif dan $R \& D$. Bandung: Alfabeta, 2015.

Sukarno. "Pengaruh Penggunaan Media Pembelajaran Terhadap Prestasi Belajar Pendidikan Agama Islam Siswa Kelas XI IPA SMA N 3 Semarang." Skripsi, UIN Walisongo, 2009.

http://eprints.walisongo.ac.id/11342/.

Suprihatiningrum, Jamil. Strategi Pembelajaran Teori \& Aplikasi. Yogyakarta: Ar-Ruzz Media, 2013.

Sutrisno, Valiant Lukad Perdana, dan Budi Tri Siswanto. "Faktor-Faktor Yang Mempengaruhi Hasil Belajar Siswa Pada Pembelajaran Praktik Kelistrikan Otomotif SMK Di Kota Yogyakarta." Jurnal Pendidikan Vokasi 6, no. 1 (2016): 111. https://doi.org/10.21831/jpv.v6i1.8118. Syarifuddin, Ahmad. "Penerapan Model Pembelajaran Cooperative Belajar Dan Faktor-Faktor Yang Mempengaruhinya." Ta'dib: Jurnal Pendidikan Islam 16, no. 01 (2011): 113. http://jurnal.radenfatah.ac.id/index.php/tadib/article/view/57.

Thoha, Mohammad. "Pembelajaran Bahasa Arab Dengan Pendekatan Manajemen Berbasis Sekolah." OKARA: Jurnal Bahasa Dan Sastra 6, no. 1 (2012).

http://ejournal.iainmadura.ac.id/index.php/okara/article/view/420. 